\title{
Characterisation of used traction sand for utilization aspects in earth construction based on the requirements of Finnish environmental legislation
}

\author{
Risto Pöykiö ${ }^{1}$, Mika Grönvall ${ }^{2}$, Gary Watkins ${ }^{3}$, Ilkka Välimäki ${ }^{4}$, Paavo Perämäki ${ }^{5}$, \\ Olli Dahl ${ }^{3}$ \\ ${ }^{1}$ Department of Environmental Protection; City of Kemi, Valtakatu 26, 94100 Kemi, Finland; e-mail: risto.poykio@kemi.fi \\ ${ }^{2}$ Department of Civil Engineering; City of Kemi, Valtakatu 26, 94100 Kemi, Finland \\ ${ }^{3}$ Clean Technology Research Group, Department of Bioproducts and Biosystems, School of Chemical Engineering, \\ Aalto University; P.O.Box 16300, Vuorimiehentie 1, 00076 Aalto, Finland \\ ${ }^{4}$ Eurofins Ahma Oy; Sammonkatu 8, 90570 Oulu, Finland \\ ${ }^{5}$ Research Unit of Sustainable Chemistry, University of Oulu; Erkki Koiso-Kanttilankatu 1, 90014 Oulu, Finland
}

(C) 2019 Authors. This is an open access publication, which can be used, distributed and reproduced in any medium according to the Creative Commons CC-BY 4.0 License requiring that the original work has been properly cited.

Received: 08 January 2019; accepted: 24 May 2019; first published online: 10 June 2019

\begin{abstract}
Finland launched a new Government Decree, the so-called MARA-regulation, on the utilization of certain wastes in earth construction on 1.1.2018. This statutory regulation sets limit values for the solubility of heavy metals ( $\mathrm{Sb}, \mathrm{As}, \mathrm{Ba}, \mathrm{Cd}, \mathrm{Cr}, \mathrm{Cu}, \mathrm{Pb}, \mathrm{Mo}, \mathrm{Ni}, \mathrm{Se}, \mathrm{Zn}, \mathrm{V}, \mathrm{Hg}$ ), chloride, sulphate, fluoride and dissolved organic carbon, as well as for organic substance (petroleum hydrocarbons, benzene, naphthalene, TEX (toluene, ethylbenzene and xylene), PAH-, phenolic- and PCB-compounds). In this case study, the concentrations of these harmful substances in the used traction sand collected in the city of Kemi, Northern Finland, were lower than their limit values set in the MARA-regulation. Therefore, this residue is a potential material to be used at earth construction sites such as in roads and roadways, in field and embankment structures, as well as in floor structures of industrial or storage buildings. However, if the used traction sand is to be utilized for these kinds of civil engineering purposes, an environmental permit is still needed because this material is not yet included in the scope of the MARA-regulation. This paper also gives an overview of the relevant Finnish environmental legislation on the utilization of wastes as an earth construction material.
\end{abstract}

Keywords: BCR extraction, circular economy, civil engineering, construction, MARA-regulation, recycled material, waste

\section{INTRODUCTION}

In the northern part of Scandinavia (Finland, Sweden, Norway), the Baltics (Estonia, Latvia, Lithuania), Northern United States and Canada, as well as in certain parts of Japan and Europe, snow and ice cover the soil surface during the winter season. In northern Finland, this is usually between
November and April, and in southern Finland, between December and March. One of the main challenges facing cities located in these areas is the maintenance of their roadway systems to provide safe winter driving conditions. All highways, public roads and streets are, naturally, kept open for traffic throughout the year by sweeping away snow. In order to prevent slippery conditions and 
to improve tyre-road friction, salt and abrasive traction sand are applied to roadways as anti- icing and anti-skid agents during all winter months when the weather conditions require it although studded tyres are also commonly used (Kupiainen et al. 2003). In general, the term "traction sand" refers to sand and gravel (stones), which are used to increase the level of friction for vehicular traffic on icy and snowy highways, roads and streets during winter.

In the spring, when the snow and ice have melted and the roadways have dried, the deployed traction sand is collected along the roadways as part of the road maintenance operations. This is done as soon as possible, because the grinding of traction sand into finer particles is reported to be one of the non-exhaust emission sources generating so-called "road dust", which contributes to the deterioration of air quality in the form of particulate matter $\left(\mathrm{PM}_{2.5} / \mathrm{PM}_{10}\right)$ in urban areas (Norman et al. 2016). Therefore, after winter, used traction sand creates storage and disposal problems unless cost-effective alternatives are identified and implemented for its management. It is usually deposited in landfill sites, which means that the life-cycle of this aggregate is only one winter season.

Traction sand is usually contaminated and needs to be chemically analysed for harmful substances before any re-use options can be contemplated. Inorganic and organic contaminants associated with traction sand particles as well as in road dust, are derived from various emission sources and are in addition dependent on factors such as weather, traffic characteristics, soil characteristics and other land-use related activates in the proximity (Mummullage et al. 2016). Used traction sand is classified as a waste, because it may include heavy metals and organic compounds, which may cause environmental contamination during the re-use of this residue. Therefore, prior to any reuse of this residue, information on the total and leachable (extractable) concentrations of heavy metals and other potentially harmful substances has to be obtained in order to determine if its usage is environmentally safe.

Leaching tests are widely used for assessing the release potential of heavy metals, hydrocarbons and other substance for example from car park dust and from road-deposited sediments as well as from various types of industrial by-products (ashes, mine tailings, steel slag), recycled materials (asphalt, construction and demolition waste) and waste materials (drilling waste, waste rock), used for different civil engineering purposes for roads, bicycle lanes or pavements construction (Filgueiras et al. 2002). Leaching tests can provide useful information for environmental decision-making, because they give information about the release potential of harmful substances from the sample matrix, which is needed to assess the mobility, bioavailability and toxicity of the recycled material. This study looks at the characteristics and potential utilization aspects of used traction sand as an earth construction material and the legal implication of such usage based on the requirements of Finnish national legislation on certain wastes in earth construction (MARA-regulation).

\section{BACKGROUND}

\section{Overview of the Finnish MARA-regulation}

In Finland, the utilization of wastes in earth construction is to be promoted through the Government Decree of 843/2017 on the recovery of certain wastes in earth construction. This statutory Decree is the so-called MARA-regulation and came into force on 1.1.2018 (Finlex 2017). The goal of the MARA-regulation is to reduce the regulatory burden of waste permitting. If the waste material fulfils the scope of the MARA-regulation, an environmental permit is not needed, and the material is allowed to be used as an earth construction material in roadways and roads including forest roads, in field and in embankment structures, and in the floor structure of industrial and storage buildings. However, a notification must be made to the State Supervisory Authority, which is the local Centre for Economic Development, Transport and Environment (ELY-Centre).

Waste materials which are included in the scope of MARA-regulation are: (1) crushed concrete, lightweight concrete and expanded clay aggregate waste, (2) fly ash from the combustion of coal, peat and wood-based material, bottom ash and sands from fluidized beds, (3) crushed 
brick, (4) asphalt chippings or crushed asphalt, (5) treated slag from waste combustion, (6) foundry sand, (7) lime, (8) whole tyres and shredded tyres and, (9) waste removed from a structure. The MARA-regulation sets limit values for the leachable (L/S $10 \mathrm{~L} / \mathrm{kg}$, water as extractant) concentrations of certain heavy metals ( $\mathrm{Sb}, \mathrm{As}, \mathrm{Ba}$, $\mathrm{Cd}, \mathrm{Cr}, \mathrm{Cu}, \mathrm{Pb}, \mathrm{Mo}, \mathrm{Ni}, \mathrm{Se}, \mathrm{Zn}, \mathrm{V}, \mathrm{Hg}$ ), chloride, fluoride, sulphate, and DOC (dissolved organic carbon), as well as for the total concentrations of benzene, TEX (toluene, ethylbenzene and $x y-$ lene), naphthalene, PAHs (polycyclic aromatic hydrocarbons), phenolic- and PCBs (polychlorinated biphenyls) compounds, as well as for petroleum hydrocarbons in the range of $\mathrm{C}_{10}-\mathrm{C}_{40}$. The limit values for these substances vary depending on the purpose of use of each recovered waste material.

Requirements are also set for the maximum thickness of a waste layer at earth construction sites, and depending on the site, either the covering or paving of the waste layer to protect a structure may be needed. The minimum distance of the structural layer from groundwater or a waterbody is also regulated. The MARA-regulation sets quality requirements for example to the maximum permitted granular size in treated waste combustion slag, the largest permitted lump size for concrete, lightweight concrete and asphalt waste as well as for largest permitted lump size for brick waste. Furthermore, the maximum weight of non-water-buoyant foreign material such as wood, rubber or metal in concrete chippings and crushed bricks is restricted as well as the maximum weight of materials that are lighter than water such as plastics and insulation materials in these recycled materials, too. However, in all cases, wastes which are reused at earth construction sites have to meet technical and functional requirements as well as the conditions of the site-specific plans set by the project developer. A detailed review of the requirement of the MARA-regulation as well as the EU waste codes for waste materials, which are included in the scope of application, can be found at the Finlex Data Bank, which is an online public service database of up-to-date legislative and other juridical information of Finland (Finlex 2017).

\section{MATERIALS AND METHODS}

\section{Sampling and pre-treatment of the traction sand}

The traction sand investigated in this study is a composite sample collected from 10 traction sand stockpiles located throughout the city of Kemi $\left(65^{\circ} 44^{\prime} \mathrm{N}, 24^{\circ} 35^{\prime} \mathrm{E}\right)$, a city of ca. 21,600 inhabitants located on the coast of the Bay of Bothnian, Northern Finland. These stockpiles are temporary storage sites for the traction sand that has been mechanically collected from along the roadways, before it is transported to a landfill disposal area. The typical average annual temperature in the region is between $1-3^{\circ} \mathrm{C}$, and the annual precipitation $450-550 \mathrm{~mm}$ with a relatively high proportion coming in the form of snow. Snow covers the study area for 150-200 days a year, usually between November and April.

Ten (10) subsamples with a total weight of $5 \mathrm{~kg}$ each were collected from each stockpile. Thus, the total amount of traction sand collected in this study is $50 \mathrm{~kg}$. The samples were collected on 27 April 2018 and placed into polyethylene bottles. Prior to any chemical and physical analyses, coarse branches, leaves and other extraneous materials were sieved out, the traction sand material was homogenized and crushed to obtain a particle size below $2 \mathrm{~mm}$ diameter. All physical and chemical analyses, except the sieving analyses, were determined using the above-mentioned crushed particles $(<2 \mathrm{~mm})$. In order to avoid the possible oxidation of some minerals, we carried out all chemical analyses using the sample as such instead of drying (Kosson et al. 2002). A coning and quartering method was applied repeatedly to reduce the composite traction sand sample $(50 \mathrm{~kg})$ to a size suitable for the laboratory analysis.

\section{Determination of the physical and chemical properties}

To determine the mineralogical composition of the traction sand, an X-ray diffractogram of powdered sample was obtained with a Siemens D 5000 diffractometer (Siemens AG, Karlsruhe, Germany) using $\mathrm{CuKa}$ radiation. The scan was run from $5^{\circ}$ to $80^{\circ}$ (2-theta scale) with increments of $0.02^{\circ}$ and 
a counting time of 1.0 second per step. The operating conditions were $40 \mathrm{kV}$ and $40 \mathrm{~mA}$. Peak identification was carried out with the DIFFRACplus BASIC Evaluation Package PDFMaint 12 (Bruker axs, Germany) and ICDD PDF-2 Release 2006 software package (Pennsylvania, USA).

For the determination of the particle size distribution, the traction sand was dry sieved on an automatic sieve shaker (Retsch Virbo, Haan, Germany) through stainless-steel sieves using a stack of nested sieves (DIN 4188, Retsch 5657, Haan, Germany) with the following particle size fractions (in mm): $>2,2-1,1-0.5,0.5-0.25,0.25-$ $0.125,0.125-0.075$ and $<0.075$. The weight of each fraction was recorded and the percent distribution of weight in each fraction was calculated.

The $\mathrm{pH}$ of the traction sand was determined by a $\mathrm{pH} / \mathrm{EC}$ analyser equipped with a Thermo Orion Sure Flow pH electrode (Turnhout, Belgium). The determination of $\mathrm{pH}$ was carried out according to European standard SFS-EN 13037 at a solid-to-liquid (ultrapure water) ratio of 1:5. Determination of the dry matter content (DMC) of the traction sand was carried out according to European standard SFS-EN 12880. The organic matter content, as measured by the loss-on-ignition (LOI), was determined according to European standard SFS-EN 12879. A comprehensive review of the standards and analytical methods is given elsewhere (Kilpimaa et al. 2013).

\section{Determination of the total metal concentrations}

To determine the total metal concentrations in the used traction sand, the dried sample was digested with aqua regia $\left(9 \mathrm{~mL} \mathrm{HCl}+3 \mathrm{~mL} \mathrm{HNO}_{3}\right)$ in a CEM Mars 5 microprocessor-controlled microwave oven with CEM HP 500 Teflon vessels (CEM Corp., Matthews, USA) using European standard SFS-EN 13657. This digestion method is accepted by the Finnish environmental authorities for the determination of total metal concentration in environmental samples (Kaakinen 2016).

The cooled solution was transferred to a $100 \mathrm{~mL}$ volumetric flask and diluted to volume with ultrapure water. All reagents and acids were super pure or pro analysis quality. Except for $\mathrm{Hg}$, the total element concentrations in the traction sand were determined with a Thermo Fisher Scientific iCAP6500
Duo (United Kingdom) inductively coupled plasma optical emission spectrometer (ICP-OES). The concentration of $\mathrm{Hg}$ in the traction sand was determined with a cold-vapour method using a Perkin Elmer AAnalyst 700 atomic absorption spectrometer (Norwalk, USA) equipped with a Perkin Elmer FIAS 400 and AS 90 plus auto-sampler.

\section{Determination of the water-soluble inorganic substances and DOC}

To determine the water-soluble concentrations of metals/metalloids ( $\mathrm{Sb}, \mathrm{As}, \mathrm{Ba}, \mathrm{Cd}, \mathrm{Cr}, \mathrm{Cu}, \mathrm{Pb}$, Mo, Ni, Se, Zn, V, Hg), chloride, sulphate, fluoride and dissolved organic carbon (DOC) in the traction sand, European standard SFS-EN 12457-3 was used (Sormunen \& Rantsi 2015). This procedure is a two-stage batch test at a liquid-to-solid ratio $(\mathrm{L} / \mathrm{S})$ of $2 \mathrm{~L} / \mathrm{kg}$ and $8 \mathrm{~L} / \mathrm{kg}$, with an extractant containing ultrapure water. In this procedure, the sum of the two extractable concentrations at a liquid-to-solid ratio (L/S) of $10 \mathrm{~L} / \mathrm{kg}$ is compared to the maximum allowable concentrations, which determines, whether the traction sand is allowed to be utilized as an earth construction material.

The metal concentrations in the extracts were determined with a Thermo Fisher Scientific iCAP6500 Duo (United Kingdom) inductively coupled plasma optical emission spectrometer (ICP-OES).Determination of the fluoride, sulphate and chloride concentrations in the extract was carried out according to European standard SFS-EN ISO 10304-1 using a Dionex ICS 2000 ion chromatography system with conductivity detection (Dionex Corp., USA) (Kuokkanen 2013). Determination of the DOC concentration in the extract was carried out according to European standard SFS-EN 1484 using a Leco CHN-600 analyser (Leco Inc, USA) (Gomes Correia et al. 2016).

\section{Determination of the benzene and TEX compounds}

To determine the concentrations of benzene and the cumulative content of TEX-compounds (toluene, ethylbenzene, xylene) in the traction sand, a modified ISO 22155 standard was used (Cocârță et al. 2017). In this procedure, the sample (20 g) was extracted with methanol $(10 \mathrm{~mL}$; including internal standard) for 30 minutes in orbital shaker. After shaking, $1 \mathrm{~mL}$ of extraction solution 
was transferred into a $20 \mathrm{~mL}$ headspace (HS) vial containing $10 \mathrm{~mL}$ of ultrapure water and about $2.5 \mathrm{~g}$ of $\mathrm{NaCl}$. The HS bottle was closed immediately after the sample was added. The volatile organic compounds (benzene, TEX) were analysed from this fraction by the HS/GC/MS method using an Agilent G1888/7890B/5977A HS/GC/MS analyser (USA, Wilmington, Delaware). The identification and quantification of benzene and TEX-compounds were carried out using an internal standard method.

\section{Determination of the naphthalene, $\mathrm{PAH}$, $\mathrm{PCB}$ and petroleum hydrocarbons $\left(\mathrm{C}_{10}-\mathrm{C}_{40}\right)$}

To determine the concentrations of naphthalene, cumulative content of PAH compounds (anthracene, acenaphthene, asenaphthylene, bentz(a)anthracene, benzo(a)pyrene, benzo(b)fluoranthene, benzo(g,h,i)perylene, benzo(k)fluoranthene, dibenzo(a,h)anthracene, phenanthrene, fluoranthene, fluorene, indeno(1,2,3-cd)pyrene, chrysene, naphthalene and pyrene), cumulative content of PCB compounds (congeners 28, 52, 101, 118, 138, 153 and 180) as well as the petroleum hydrocarbons $\left(\mathrm{C}_{10}-\mathrm{C}_{40}\right)$ in the traction sand, the in-house method based on standards SFS-ISO 18287 for PAHs (Paxal 2012), USEPA 3665A for PCBs (Saitta et al. 2014) and SFS-EN ISO 16703 for petroleum hydrocarbons $\left(\mathrm{C}_{10}-\mathrm{C}_{40}\right)$ (Paxal 2012) were used.

The sample $(20 \mathrm{~g})$ was extracted with a mixture of hexane $(10 \mathrm{~mL})$ and acetone $(10 \mathrm{~mL})$ for $60 \mathrm{~min}$ utes with an orbital shaker. The hexane phase was collected after phase separation and divided for PAH, PCB and petroleum hydrocarbons $\left(\mathrm{C}_{10}-\mathrm{C}_{40}\right)$ determinations. Prior to analysis, the hexane phase was purified with Florisil for the determination of petroleum hydrocarbons $\left(\mathrm{C}_{10}-\mathrm{C}_{40}\right)$ and with sulphuric acid for the determination of PCBs. Petroleum hydrocarbons $\left(\mathrm{C}_{10}-\mathrm{C}_{40}\right)$ and PAHs were determined separately with GC/MS using an Agilent 5975B/6890N GC/MS analyser (USA, Wilmington, Delaware). The identification and quantification of naphthalene, $\mathrm{PAH}, \mathrm{PCB}$ and petroleum hydrocarbons $\left(\mathrm{C}_{10}-\mathrm{C}_{40}\right)$ were carried out using an internal standard method.

\section{Determination of the phenolic compounds}

The cumulative content of phenolic compounds (phenol, o-cresol, m-cresol, $\mathrm{p}$-cresol and bisphenol-A) in the traction sand were determined after extraction and derivatization as phenolic acetate using GC/MS analyser (Sinkkonen et al. 2012). The sample $(10 \mathrm{~g})$ was extracted with an alkaline extraction solution containing of $30 \mathrm{~mL} 0.1 \mathrm{M}$ $\mathrm{NaOH}$ and $30 \mathrm{~mL} 0.1 \mathrm{M} \mathrm{K}_{2} \mathrm{CO}_{3}$ in an orbital shaker for 60 minutes. The extracted phenolic compounds were then acetylated and extracted into hexane. Finally, the derived compounds in the extract were determined by GC/MS using an Agilent 5975B/6890N GC/MS (USA, Wilmington, Delaware). The identification and quantification of phenolic compounds were carried out using an internal standard method.

\section{BCR extraction of heavy metals}

For the fractionation of heavy metals in the used traction sand between the exchangeable fraction (Step 1), reducible fraction (Step 2) and oxidizable fraction (Step 3), the original three-stage BCR sequential extraction procedure was used (Adamiec 2017). Briefly, in this extraction procedure about $5 \mathrm{~g}$ of traction sand was transferred to a polypropylene bottle and sequentially extracted in the following way:

- Step 1 (exchangeable fraction):

$200 \mathrm{~mL} 0.1 \mathrm{M}$ acetic acid $\left(\mathrm{CH}_{3} \mathrm{COOH}, \mathrm{pH} 3.0\right.$; shaking for $16 \mathrm{~h}$ at $25^{\circ} \mathrm{C}$ ),

- Step 2 (reducible fraction):

residue $+200 \mathrm{~mL} 0.1 \mathrm{M}$ hydroxylamine hydrochloride $\left(\mathrm{NH}_{2} \mathrm{OH}-\mathrm{HCl}\right)$ (adjusted to $\mathrm{pH} 1.5$ with $\mathrm{HNO}_{3}$; shaking for $16 \mathrm{~h}$ at $25^{\circ} \mathrm{C}$ ),

- Step 3 (oxidizable fraction):

residue $+250 \mathrm{~mL} 1.0 \mathrm{M}$ ammonium acetate $\left(\mathrm{CH}_{3} \mathrm{COONH}{ }_{4}\right.$, adjusted to $\mathrm{pH} 2.0$ with $\mathrm{HNO}_{3}$; shaking for $16 \mathrm{~h}$ at $25^{\circ} \mathrm{C}$ ) after the hydrogen peroxide $\left(50 \mathrm{~mL} 30 \% \mathrm{H}_{2} \mathrm{O}_{2}\right.$ ) digestion $(1 \mathrm{~h}$ at $85^{\circ} \mathrm{C}$, evaporation, twice).

This extraction procedure is validated and harmonized by the European Community Bureau of Reference (BCR), nowadays the European Community (EC) Standards, Measurements and Testing Programme and therefore it is in the literature known as a BCR-extraction method. The widely used abbreviation for the exchangeable fraction in Step 1 is "BCR1", correspondingly "BCR2" for the reducible fraction in Step 2 and "BCR3" for the oxidizable fraction in Step 3, which are used in this paper, too. The heavy metal concentrations in the extracts were determined with a Thermo Fisher Scientific iCAP6500 Duo (United Kingdom) 
inductively coupled plasma optical emission spectrometer (ICP-OES).

In order to avoid possible chemical and/or microbiological changes in the sample, the extraction was carried out using the sample as such, instead of a dried sample, since according to Kosson et al. (2002), it is preferable to avoid sample drying before extraction. After each extraction step, the extract was separated from the solid residue by filtration through a $0.45 \mu \mathrm{m}$ filter $(47 \mathrm{~mm}$ diameter; Schleicher \& Schuell, Dassel, Germany). After addition of $200 \mathrm{~mL}$ of $65 \% \mathrm{HNO}_{3}$ in the supernatant phase, it was stored in a refrigerator $\left(+4^{\circ} \mathrm{C}\right)$ until heavy metal determination.

\section{RESULTS AND DISCUSSION}

When the potential utilization aspects for mineral wastes in different civil engineering purposes are evaluated, the key factor is whether the residues meet the requirements of the relevant environmental laws and national regulations. Therefore, in the following paragraphs of this study, we have focused on the main important chemical and especially extraction properties of the investigated traction sand from the utilization point of view, based on the regulations of Finnish environmental legislation, and especially on the MARA-regulation.

According to the Table 1, the water extractable $(\mathrm{L} / \mathrm{S} 10 \mathrm{~L} / \mathrm{kg})$ concentrations of inorganic contaminants, as well dissolved organic carbon (DOC) content in the traction sand were clearly lower than their corresponding limit values for recovered wastes set in the MARA-regulation. The slightly elevated DOC concentration $(68 \mathrm{mg} / \mathrm{kg} ; \mathrm{d} . \mathrm{m}$.) is most probably due to small pieces of leaves and branches, which accumulate on street surface and pulverized by passing traffic. These were impossible to remove during the pre-treatment of the material prior any chemical analysis. Although salt is also used as a de-icing agent for main urban highways and streets in the investigated study area and elsewhere in Finland during winter maintenance when temperatures are a few degrees below freezing, the soluble chloride content in the traction sand investigated was negligible (<50 mg/kg; d.m.).

\section{Table 1}

Water extractable concentrations $[\mathrm{mg} / \mathrm{kg} ; \mathrm{d} . \mathrm{m}$.] at a liquid-to-solid ratio of $10 \mathrm{~L} / \mathrm{kg}$ of inorganic substances and dissolved organic carbon (DOC) in the used traction sand investigated in this study and their corresponding Finnish limit values [mg/kg; d.m.] for different structures at earth construction sites

\begin{tabular}{|c|c|c|c|c|c|c|c|c|}
\hline \multirow[b]{2}{*}{ Substance } & \multirow[b]{2}{*}{$\begin{array}{c}\text { Traction } \\
\text { sand } \\
(n=1)\end{array}$} & \multicolumn{7}{|c|}{ Limit value at earth construction site [mg/kg; d.m.] } \\
\hline & & $\begin{array}{l}\text { Roadway } \\
\text { (covered) }\end{array}$ & $\begin{array}{l}\text { Roadway } \\
\text { (paved) }\end{array}$ & $\begin{array}{c}\text { Field } \\
\text { (covered) }\end{array}$ & $\begin{array}{c}\text { Field } \\
\text { (paved) }\end{array}$ & $\begin{array}{c}\text { Embank- } \\
\text { ment } \\
\text { (covered) }\end{array}$ & $\begin{array}{l}\text { Floor structure } \\
\text { of industrial or } \\
\text { storage building }\end{array}$ & $\begin{array}{l}\text { Road construct- } \\
\text { ed of crushed } \\
\text { stone and ash }\end{array}$ \\
\hline $\mathrm{Sb}$ & $<0.01$ & 0.7 & 0.7 & 0.3 & 0.7 & 0.7 & 0.7 & 0.7 \\
\hline As & 0.02 & 1.0 & 2.0 & 0.5 & 1.5 & 0.5 & 2.0 & 2.0 \\
\hline $\mathrm{Ba}$ & 0.09 & 40.0 & 100.0 & 20.0 & 60.0 & 20.0 & 100.0 & 80.0 \\
\hline $\mathrm{Cd}$ & $<0.01$ & 0.04 & 0.06 & 0.04 & 0.06 & 0.04 & 0.06 & 0.06 \\
\hline $\mathrm{Cr}$ & 0.02 & 2.0 & 10.0 & 0.5 & 5.0 & 1.0 & 10.0 & 5.0 \\
\hline $\mathrm{Cu}$ & 0.06 & 10.0 & 10.0 & 2.0 & 10.0 & 10.0 & 10.0 & 10.0 \\
\hline $\mathrm{Pb}$ & $<0.01$ & 0.5 & 2.0 & 0.5 & 2.0 & 0.5 & 2.0 & 1.0 \\
\hline Mo & 0.01 & 1.5 & 6.0 & 0.5 & 6.0 & 1.0 & 6.0 & 2.0 \\
\hline $\mathrm{Ni}$ & 0.01 & 2.0 & 2.0 & 0.4 & 1.2 & 1.2 & 2.0 & 2.0 \\
\hline $\mathrm{Se}$ & $<0.04$ & 1.0 & 1.0 & 0.4 & 1.0 & 1.0 & 1.0 & 1.0 \\
\hline $\mathrm{Zn}$ & $<0.05$ & 15.0 & 15.0 & 4.0 & 12.0 & 15.0 & 15.0 & 15.0 \\
\hline $\mathrm{V}$ & 0.04 & 2.0 & 3.0 & 2.0 & 3.0 & 2.0 & 3.0 & 3.0 \\
\hline $\mathrm{Hg}$ & $<0.004$ & 0.03 & 0.03 & 0.01 & 0.03 & 0.03 & 0.03 & 0.03 \\
\hline $\mathrm{Cl}^{-}$ & $<50.0$ & 3,200 & 11,000 & 800 & 2400 & 1,800 & 11,000 & 4,700 \\
\hline $\mathrm{SO}_{4}^{2-}$ & $<50.0$ & 5,900 & 18,000 & 1,200 & 10,000 & 3,400 & 18,000 & 6,500 \\
\hline $\mathrm{F}^{-}$ & $<5.0$ & 50 & 150 & 10 & 50 & 30 & 150 & 100 \\
\hline DOC & 68 & 500 & 500 & 500 & 500 & 500 & 500 & 500 \\
\hline
\end{tabular}


Furthermore, according to Table 2, the total concentrations of organic substances in the traction sand were also clearly lower than their corresponding limit values set in the MARA-regulation. These results suggest that the traction sand is a material with the potential to be used as an earth construction agent. However, due to the fact that the traction sand material description is not included in the scope of the MARA-regulation, an environmental permit is needed if this residue is to be utilized at any construction site in roads and roadways, fields, or in the structures of embankment or industrial or storage buildings. The elevated petroleum hydrocarbons $\left(\mathrm{C}_{10}-\mathrm{C}_{40}\right)$ concentration of $150 \mathrm{mg} / \mathrm{kg}$ (d.m.) in the traction sand indicates possible leakages from vehicles' tanks, although they may be partly derived also from leakage lubricants, from the abrasion of road material (asphalt) and the wear of tyres.

Table 2

Total concentrations $[\mathrm{mg} / \mathrm{kg} ; \mathrm{d} . \mathrm{m}$.] of organic substances in the used traction sand investigated in this study and their corresponding Finnish limit values [mg/kg; d.m.] for different structures at earth construction sites

\begin{tabular}{|c|c|c|c|c|c|c|c|c|}
\hline \multirow[b]{2}{*}{ Substance } & \multirow{2}{*}{$\begin{array}{c}\text { Traction } \\
\text { sand } \\
(n=1)\end{array}$} & \multicolumn{7}{|c|}{ Limit value at earth construction site [mg/kg; d.m.] } \\
\hline & & $\begin{array}{l}\text { Roadway } \\
\text { (covered) }\end{array}$ & $\begin{array}{c}\text { Roadway } \\
\text { (paved) }\end{array}$ & $\begin{array}{c}\text { Field } \\
\text { (covered) }\end{array}$ & $\begin{array}{c}\text { Field } \\
\text { (paved) }\end{array}$ & $\begin{array}{l}\text { Embank- } \\
\text { ment } \\
\text { (covered) }\end{array}$ & $\begin{array}{l}\text { Floor structure } \\
\text { of industrial or } \\
\text { storage building }\end{array}$ & $\begin{array}{l}\text { Road construct- } \\
\text { ed of crushed } \\
\text { stone and ash }\end{array}$ \\
\hline Benzene & $<0.02$ & 0.20 & 0.20 & 0.02 & 0.20 & 0.06 & 0.02 & 0.20 \\
\hline TEX & $<0.10$ & 25.0 & 25.0 & 25.0 & 25.0 & 25.0 & 10.0 & 25.0 \\
\hline Naphthalene & $<0.10$ & 5.0 & 5.0 & 5.0 & 5.0 & 5.0 & 5.0 & 5.0 \\
\hline PAH & $<0.10$ & 30.0 & 30.0 & 30.0 & 30.0 & 30.0 & 30.0 & 30.0 \\
\hline Phenolic & $<0.25$ & 10.0 & 10.0 & 5.0 & 10.0 & 10.0 & 10.0 & 10.0 \\
\hline PCB & $<0.01$ & 1.0 & 1.0 & 1.0 & 1.0 & 1.0 & 1.0 & 1.0 \\
\hline $\mathrm{C}_{10}-\mathrm{C}_{40}$ & 150 & 500 & 500 & 500 & 500 & 500 & 300 & 500 \\
\hline
\end{tabular}

\section{Physical and chemical properties of the traction sand}

According to the X-ray diffraction (XRD) data, dolomite $\left(\mathrm{CaMg}\left(\mathrm{CO}_{3}\right)_{2}\right)$, which is a carbonate mineral, was the most abundant mineral (37.6\%). Other minerals observed by the XRD in this residue were silicates such as quartz $\left(\mathrm{SiO}_{2} ; 22.7 \%\right)$, phlogopite $\left.\left(\mathrm{KMg}_{3} \mathrm{AlSi}_{3} \mathrm{O}_{10}(\mathrm{~F}, \mathrm{OH})_{2}\right) ; 7.0 \%\right)$, anorthite $\left(\mathrm{CaAl}_{2} \mathrm{Si}_{2} \mathrm{O}_{8} ; 4.2 \%\right)$, albite $\left(\mathrm{NaAlSi}_{3} \mathrm{O}_{8}\right.$; $11.8 \%)$, microcline $\left(\mathrm{KAlSi}_{3} \mathrm{O}_{8} ; 14.2 \%\right)$ and chamosite $\left.\left(\mathrm{Fe}^{2+}, \mathrm{Mg}\right)_{5} \mathrm{Al}\left(\mathrm{AlSi}_{3} \mathrm{O}_{10}\right)(\mathrm{OH})_{8} ; 2.5 \%\right)$. In this context it is worth noting that the detection limit of the XRD technique is normally $1-2 \%(\mathrm{w} / \mathrm{w})$. This is the reason why all of the elements in Table 1 and Table 3 were not identified by XRD, despite the fact that the concentrations of these elements could be quantitatively measured by ICP-OES.
The water extraction of traction sand generated a neutral or slightly basic solution ( $\mathrm{pH} 7.8$ ). This is reasonable because the Mg- and Ca-bearing silicates which were observed by XRD may provide some neutralization capacity (Räisänen et al. 2010). According to low electrical conductivity $(23 \mathrm{mS} / \mathrm{m})$ value, it is unlikely that the used traction sand could cause salinity problems if utilized. Due to its geogenic origin, the dry matter content (DMC) in the traction sand was very high (95\%) and organic matter content expressed as loss-on-ignition (LOI) value was very low (1.4\%). The particles in the range between $0.5-31.5 \mathrm{~mm}$ in diameter accounted ca. $70 \%$ of the traction sand weight, whereas the particle smaller than $0.075 \mathrm{~mm}$ in diameter accounted only $4 \%$. This result, together with the high bulk density value of $1400 \mathrm{~kg} / \mathrm{m}^{3}$, indicates that the handling of traction sand as such does not cause dust problems easily. 
Table 3

Total (aqua regia) and BCR extractable concentrations [mg/kg; d.m.] of inorganic substances in the used traction sand investigated in this study as well as the sum of extractable concentrations and the recovery values [\%] for elements' extractability

\begin{tabular}{|c|c|c|c|c|c|c|}
\hline \multirow{2}{*}{ Substance } & \multirow{2}{*}{$\begin{array}{c}\text { Total } \\
(n=3)\end{array}$} & \multicolumn{5}{|c|}{ BCR extractable } \\
\hline & & BCR1 & BCR2 & BCR3 & Sum & Recovery [\%] \\
\hline $\mathrm{Al}$ & $8,570 \pm 495$ & $50 \pm 1.2$ & $433 \pm 23$ & $303 \pm 21$ & 786 & 9.2 \\
\hline $\mathrm{Fe}$ & $21,034 \pm 404$ & $990 \pm 36$ & $1,650 \pm 30$ & $353 \pm 25$ & 2,993 & 14.3 \\
\hline $\mathrm{Mn}$ & $227 \pm 6.0$ & $59 \pm 4.0$ & $45 \pm 6.8$ & $8.5 \pm 0.5$ & 112.5 & 49.5 \\
\hline $\mathrm{Ca}$ & $21,767 \pm 1,665$ & $18,066 \pm 252$ & $14,667 \pm 1,069$ & $497 \pm 65$ & 33,230 & 153 \\
\hline $\mathrm{K}$ & $2,550 \pm 282$ & $353 \pm 21$ & $89 \pm 4.7$ & $158 \pm 18$ & 600 & 23.5 \\
\hline $\mathrm{P}$ & $363 \pm 15$ & $5.8 \pm 0.5$ & $268 \pm 4.0$ & $16 \pm 3.2$ & 289.8 & 79.8 \\
\hline $\mathrm{Mg}$ & $18,567 \pm 1,595$ & $9,410 \pm 372$ & $8,020 \pm 656$ & $517 \pm 46$ & 17,947 & 96.7 \\
\hline $\mathrm{Na}$ & $487 \pm 12$ & $42 \pm 1.5$ & $23 \pm 1.2$ & $42 \pm 4.2$ & 107 & 21.9 \\
\hline $\mathrm{Ba}$ & $53 \pm 5.1$ & $11 \pm 1.0$ & $5.5 \pm 0.3$ & $3.4 \pm 0.3$ & 19.9 & 37.5 \\
\hline $\mathrm{Cd}$ & $<0.3$ & $<0.06$ & $<0.06$ & $<0.08$ & $<0.2$ & - \\
\hline $\mathrm{Cr}$ & $570 \pm 17$ & $1.8 \pm 0.2$ & $28 \pm 1.7$ & $43 \pm 3.7$ & 72.8 & 12.8 \\
\hline $\mathrm{Cu}$ & $32 \pm 2.0$ & $2.1 \pm 0.1$ & $3.9 \pm 0.4$ & $13 \pm 2.3$ & 19 & 59.4 \\
\hline $\mathrm{Pb}$ & $3.4 \pm 0.4$ & $<0.6$ & $1.6 \pm 0.2$ & $<0.8$ & $<3.0$ & - \\
\hline Mo & $<0.2$ & $<0.2$ & $<0.2$ & $<0.2$ & $<0.6$ & - \\
\hline $\mathrm{Ni}$ & $36 \pm 2.0$ & $1.6 \pm 0.0$ & $3.8 \pm 0.1$ & $3.9 \pm 0.4$ & 9.3 & 25.8 \\
\hline $\mathrm{Zn}$ & $36 \pm 1.0$ & $9.5 \pm 0.4$ & $5.9 \pm 0.1$ & $5.6 \pm 0.3$ & 21.0 & 58.3 \\
\hline $\mathrm{V}$ & $51 \pm 1.0$ & $<0.4$ & $2.3 \pm 0.2$ & $3.4 \pm 0.4$ & $<6.1$ & - \\
\hline
\end{tabular}

\section{Total metal concentrations in the traction sand}

According to results in Table 3, the highest total metal concentrations after aqua regia digestion were observed for $\mathrm{Ca}(21,767 \mathrm{mg} / \mathrm{kg}$; d.m.), Fe (21,034 mg/kg; d.m.), Mg (18,567 mg/kg; d.m.), Al $\quad(8,570 \mathrm{mg} / \mathrm{kg} ;$ d.m. $), \quad \mathrm{K} \quad(2,550 \mathrm{mg} / \mathrm{kg} ;$ d.m. $)$ and $\mathrm{Na}(487 \mathrm{mg} / \mathrm{kg} ; \mathrm{d} . \mathrm{m}$.). If we compare the total metal concentrations in the traction sand investigated in this study to those reported by Kaila (2015) for the traction sand collected at the city of Turku, southwest Finland, the total concentration for $\mathrm{Cr}(570 \mathrm{mg} / \mathrm{kg}$; d.m.) in this residue was clearly higher than that in Turku (45-54 mg/kg; d.m.), as too was the Ni concentration $(36 \mathrm{mg} / \mathrm{kg}$; d.m.), which varied between $17-19 \mathrm{mg} / \mathrm{kg}$ (d.w.) in Turku. However, the total concentration of $\mathrm{Zn}(36 \mathrm{mg} / \mathrm{kg}$; d.m.) in the traction sand investigated in this study was clearly lower than that in Turku (84-100 mg/kg; d.m.). These results indicate the different origin of the traction sands used at these cities, although part of metals in the sand materials may also be contaminants derived from the road surface wear, road paint degradation, vehicle wear of tyres, body and brake linings as well as from the particulate emissions from the roadside soils (Botsou et al. 2016).

\section{BCR extractable heavy metals in the traction sand}

The objective of the extractions in the 3-step BCR sequential extraction procedure, which was also used in this study, is to simulate the mobilization of the heavy metals in specific environmental conditions that could affect metal-binding in the solid surfaces, such as acidification, reduction and oxidation (Rao et al. 2008). The potential mobility and ecotoxicity of heavy metals are determined by their specific binding forms and coupled reactivity, rather than their total concentrations.

According to the results presented in $\mathrm{Ta}$ ble 3, the highest extractable metal concentrations in the BCR1 fraction, in which $\mathrm{CH}_{3} \mathrm{COOH}$ was used as an extractant, were observed for Ca (18,066 mg/kg; d.m.), Mg (9,410 mg/kg; d.m.), Fe $(990 \mathrm{mg} / \mathrm{kg}$; d.m.) and $\mathrm{K}(353 \mathrm{mg} / \mathrm{mg}$; d.m.), following the moderate extractable concentrations of Mn (59 mg/kg; d.m.), $\mathrm{Al}(50 \mathrm{mg} / \mathrm{kg}$; d.m.) and $\mathrm{Na}(42 \mathrm{mg} / \mathrm{kg}$; d.m.). In general, metals present in ionic form, bound to carbonates and the 
exchangeable fraction, are released in this extraction step (Ptistišek et al. 2001). The metals which are released in this extraction step are loosely bound compounds and are considered as "potential available" for environmental point of view. This fraction represents the natural environmental effects of acidic rainwater percolation (Rodgers et al.2015). Carbonate minerals are easily reactive, mainly in acidic environments (Gruszecka-Kosowska et al. 2015). Therefore, due to the acidic nature ( $\mathrm{pH}$ 3.0) of the extractant, it is very likely that the Ca extracted in this fraction is mostly released from the dolomite $\left(\mathrm{CaMg}\left(\mathrm{CO}_{3}\right)_{2}\right)$ particles in the traction sand.

According to results in Table 3, the highest extractable metal concentrations in the BCR2 fraction, in which a reducing extractant $\mathrm{NH}_{2} \mathrm{OH}-\mathrm{HCl}$ in nitric acid $\left(\mathrm{HNO}_{3}\right)$ media was used, were observed for $\mathrm{Ca}(14,667 \mathrm{mg} / \mathrm{kg}$; d.m.), Mg (8,020 mg/kg; d.m.), Fe (1,650 mg/kg; d.m.), Al (433 mg/mg; d.m.) and P (268 mg/kg; d.m.). In general, metals bound to amorphous iron, manganese oxides and hydroxides are released in this extraction step and they can be mobilized under suboxic and anoxic (reducing) conditions (Filgueiras et al. 2002). From the environmental point of view, metals bound into oxide phases are not considered to be very mobile or available (Smichowski et al. 2005). However, when incorporated with other compounds in the environment (e.g. by adsorption, desorption or ion exchange, etc.), they can be slowly released over time (Rodgers et al. 2015). Due to the acidic nature ( $\mathrm{pH}$ 1.5) of extractant, it is very likely that Ca extracted in this fraction is released mostly from the dolomite $\left(\mathrm{CaMg}\left(\mathrm{CO}_{3}\right)_{2}\right)$ particles in the traction sand, since according to Helios Rybicka \& Calmano (1988), also hydroxylamine hydrochloride extract $\mathrm{Ca}$ and Mg effectively.

According to the results supplied in Table 3, the highest extractable metal concentrations in the BCR3 fraction, in which the sample was first digested with the $\mathrm{H}_{2} \mathrm{O}_{2}$ following the extraction with $\mathrm{CH}_{3} \mathrm{COONH}_{4}$, were observed for Mg (517 mg/kg; d.m.), Ca (497 mg/kg; d.m.), Fe (353 mg/kg; d.m.), Al (303 mg/kg; d.m.) and $\mathrm{K}(158 \mathrm{mg} / \mathrm{kg}$; d.m.). In general, metals strongly attached to organic matter and oxidizable minerals such as sulphides and phosphates are released in this extraction step (Rocco \& Rubio 2009). Heavy metals in this fraction are assumed to remain within the solid matrix and are mobilized after a significant period of time, usually by the decomposition of organic matter (Rodgers et al. 2015). In our case, the extractability of $P$ was only $16 \mathrm{mg} / \mathrm{kg}$ (d.m.) in this fraction, which is ca. $4.4 \%$ of the phosphorous total concentration $(363 \mathrm{mg} / \mathrm{kg}$; d.m.). According to Gruszecka-Kosowska \& Mikoda (2015), it is crucial to know the dissolved forms of phosphorous, because if released from the sample matrix, it may cause eutrophication during the reuse of recycled materials.

In this study, the BCR extraction procedure released calcium more effectively from the sample matrix than did the aqua regia alone. This together with the fact that the lithium tetraborate $\left(\mathrm{Li}_{2} \mathrm{~B}_{4} \mathrm{O}_{7}\right)$ alkaline fusion digestion gave the $\mathrm{Ca}$ concentration of $41,000 \mathrm{mg} / \mathrm{kg}$ (d.m.) for the investigated traction sand, which is ca. 1.9 times higher than the value of $21,767 \mathrm{mg} / \mathrm{kg}$ (d.m.) reported in Table 3 after aqua regia digestion, supports the findings of Gaudino et al. (2007) that aqua regia digestion provides only a "partial" extraction for most rock forming elements and elements of a refractory nature.

If we disregard the heavy metals whose concentrations were lower than the detection limits, then according to Table 3, the lowest total extractability (sum of extraction steps 1-3) compared to the corresponding total element concentration (aqua regia digestion) in the traction sand was observed for $\mathrm{Al}(9.2 \%)$ and the highest for $\mathrm{Ca}$ (153\%). In this context it is also worth noting that Tokalioğlu et al. (2003) observed higher heavy metal recoveries for highways soil samples using the BCR sequential extraction than when aqua regia digestion was used. However, although certain metals were relatively easy to release from the sample matrix using the BCR extraction, based on the recovery values in Table 3, which express the ratios of elements BCR extractable concentration to their total element concentration, we conclude that most heavy metals in the traction sand investigated were relatively tightly bound to the sample matrix supporting the further utilization of this residue. 


\section{CONCLUSIONS}

The concentrations of the harmful substances in the used traction sand collected at the city of Kemi, Northern Finland, were lower than their limit values set in the MARA-regulation, which is the Finnish Government Decree on the recovery of certain wastes in earth construction (843/2017) and came into force on 1.1.2018. Therefore, the traction sand investigated is a potential material to be reused in civil engineering purposes such as in roads and roadways, in field and embankment structures, as well as in floor structures of industrial or storage buildings. However, due to the fact that this material is not yet specifically included within the scope of the MARA regulation, an environmental permit is still needed if this residue is to be utilized in these kinds of reuse applications.

From the perspective of the circular economy, if the used traction sand could be re-used and recycled as an earth construction material instead of going to landfill disposal, the following benefits may be archived:

- it reduces the amount of virgin aggregates that need to be obtained, leading to reduced extraction of natural resources; the city of Kemi applies ca. 3,000 tonnes of traction sand each winter and in Finland, this amount is approximately 1.3 million tonnes per year;

- the recycled aggregate is regarded as a "green" construction material, thus encouraging municipality endeavours towards a more eco-friendly society; the city of Kemi is committed to the sustainable development of United Nations (UN) and a "Green Kemi" model is included in the city strategy;

- it conserves landfill space or even the need for new landfills; the used traction sand creates storage and disposal problem because there is only one municipal landfill in the study area;

- it saves money on possible landfill taxes; the Finnish tax on waste landfill has been $70 € / \mathrm{t}$ since 1.1.2016. If the used traction sand is landfilled, it will cost ca. $€ 210,000$ per year for the city of Kemi;

- may create jobs, if used as a raw material for another industry; one important goal of the city strategy at Kemi includes creating jobs in the field of circular economy.
The authors wish to thank the laboratory staff of Eurofins Ahma Oy, who kindly conducted all the chemical analyses. Their thanks are also extended to the technical staff at Centre of Microscopy and Nanotechnology (CMNT) Research Unit of University of Oulu, for the XRD data.

\section{REFERENCES}

Adamiec E., 2017. Chemical fractionation and mobility of traffic-related elements in road environments. Environmental Geochemistry Health, 39, 6, 1457-1468. DOI: https://doi.org/10.1007/s10653-017-9983-9.

Botsou F., Sungur A., Kelepertzis E. \& Soylak M., 2016. Insights into the chemical partitioning of trace metals in roadside and off-road agricultural soils along two major highways in Attica's region, Greece. Ecotoxicology and Environmental Safety, 132, 101-110. DOI: https://doi. org/10.1016/j.ecoenv.2016.05.032.

Cocârță d.m., Stoian M.A. \& Karademir A., 2017. Crude oil contaminated sites: Evaluation by using risk assessment approach. Sustainability, 9, 8, art. no. 1365, 16 p. DOI: https://doi.org/10.3390/su9081365.

Filgueiras A.V., Lavilla I. \& Bendicho C., 2002. Chemical sequential extraction for metal partitioning in environmental solid samples. Journal of Environmental Monitoring, 4, 6, 823-857. DOI: https:/doi.org/10.1039/ b207574c.

Finlex, 2017. Valtioneuvoston asetus eräiden jätteiden hyödyntämisestä maarakentamisessa (843/2017). Annettu 7 päivänä joulukuuta 2017 [Government Decree on the Recovery of Certain Wastes in Earth Construction (843/2017]. Ministry of the Environment, Finland, Helsinki, 7 December 2017, [on-line:] https://www.finlex.fi/ fi/laki/alkup/2017/20170843 [access 31.01.2018].

Gaudino S., Galas C., Belli M., Barbizzi S., de Zorzi P., Jaćimović R., Jeran Z., Pati A. \& Sansone U., 2007. The role of different soil sample digestion methods on trace elements analysis: a comparison of ICP-MS and INAA measurement results. Accreditation and Quality Assurance, 12, 2, 84-93. DOI: https://doi.org/10.1007/s00769-006-0238-1.

Gomes Correia A., Winter M.G. \& Puppala A.J., 2016. A review of sustainable approaches in transport infrastructure geotechnics. Transportation Geotechnics, 7, 21-28. DOI: https://doi.org/10.1016/j.trgeo.2016.03.003.

Gruszecka-Kosowska A. \& Mikoda B., 2015. Commercial utilization of mineral waste: review of analysis methods determining its compliance with environmental laws. Geology, Geophysics \& Environment, 41, 3, 263-274. DOI: http://dx.doi.org/10.7494/geol.2015.41.3.263.

Gruszecka-Kosowska A., Wdowin M., Kosowski T. \& Klimek A., 2015. An analysis of the chemistry, mineralogy and texture of waste dolomite powder used to identify its potential application in industry. Geology, Geophysics \& Environment, 41, 4, 343-352. DOI: http://dx.doi. org/10.7494/geol.2015.41.4.343.

Helios Rybicka E. \& Calmano W., 1988. Changes in physico-chemical properties of some clay minerals by reducing extraction reagents. Applied Clay Sciences, 3, 1, 75-84. DOI: https://doi.org/10.1016/01691317(88)90007-5. 
Kaakinen J., 2016. Öljyllä ja raskasmetalleilla pilaantuneita maita koskevan ympäristölainsäädännön ja lupamenettelyn edistäminen kemiallisella tutkimuksella [Chemical studies of oil and heavy metals contaminated soils to promote environmental legislation and permit process]. University of Oulu, Oulu, Finland [Ph.D.thesis], [on-line:] http://urn.fi/urn:isbn:9789526211589 [access: 15.04.2016].

Kaila O., 2015. Hiekoitussepelin elinkaari ja uusiokäyttö Turun kaupungissa [The life-cycle and material recovery of anti-skid aggregate in the city of Turku]. Turku University of Applied Sciences, Turku, Finland [Bachelor's thesis], [on-line:]: https://www.theseus.fi/handle/10024/96133 [access 10.05.2018].

Kilpimaa S., Kuokkanen T. \& Lassi U., 2013. Characterization and utilization potential of wood ash from combustion process and carbon residue from gasification process. BioResources, 8, 1, 1011-1027.

Kosson D.S., van derSloot H.A., Sanchez F. \& Garrabrants A.C., 2002. An integrated framework for evaluating leaching in waste management and utilization of secondary materials. Environmental Engineering Science, 19, 3, 159-204. DOI: https://doi.org/10.1089/109287502760079188.

Kuokkanen M., 2013. Development of an eco- and material-efficient pellet production chain - A chemical study. University of Oulu, Oulu, Finland [Ph.D. thesis], [on-line:] http://urn.fi/urn:isbn:9789526201047 [access 26.04.2013].

Kupiainen K., Tervahattu H. \& Räisänen M., 2003. Experimental studies about the impact of traction sand on urban road dust composition. The Science of Total Environment, 308, 1-3, 175-184. DOI: https://doi.org/10.1016/ S0048-9697(02)00674-5.

Mummullage S., Egodawatta P., Ayoko G.A. \& Goonetilleke A., 2016. Sources of hydrocarbons in urban road dust: Identification, quantification and prediction. Environmental Pollution, 216, 80-85. DOI: https://doi. org/10.1016/j.envpol.2016.05.042.

Norman M., Sundvor I., Dendy B.R., Johansson C., Gustafsson M., Blomqvist G. \& Janhäll S., 2016. Modelling road dust emission abatement measures using the NORTRIP model: Vehicle speed and studded tyre reduction. At mospheric Environment, 134, 96-108. DOI: https://doi. org/10.1016/j.atmosenv.2016.03.035.

Paxal P., 2012. Öljyllä saastuneiden maanäytteiden alifaattisten öljyhiilivetyjen ja PAH-yhdisteiden määrittäminen GC-FID- ja GC-MS-tekniikalla [Determination of aliphatic petroleum hydrocarbons and PAHs from oil-contaminated soil samples by GC-FID and GC-MS]. Metropolia University of Applied Sciences, Helsinki, Finland [Bachelor's thesis], [on-line:] https://www.theseus.fi/handle/10024/48726 [access 15.02.2017].
Ptistišek N., Milačič R. \& Veber M., 2001. Use of the BCR three-step sequential extraction procedure for the study of the partitioning of $\mathrm{Cd}, \mathrm{Pb}$ and $\mathrm{Zn}$ in various soil samples. Journal of Soils and Sediments, 1, 1, 25-29. DOI: https://doi.org/10.1007/BF02986466.

Rao C.R.M., Sahuquillo A. \& Lopez Sanchez J.F., 2008. A review of the different methods applied in environmental geochemistry for single and sequential extraction of trace elements in soils and related materials. Water, Air and Soil Pollution, 189, 1-4, 291-333. DOI: https://doi. org/10.1007/s11270-007-9564-0.

Rocco M. \& Rubio M.A., 2009. Reinterpretation of the first step of the sequential extraction proposed by the SMT. Journal of Chilean Chemical Society, 54, 3, 323-326. DOI: http://dx.doi.org/10.4067/S071797072009000300025.

Rodgers K.J., Hursthouse A. \& Cuthbert S., 2015. The potential of sequential extraction in the characterisation and management of wastes from steel processing: A prospective review. International Journal of Environmental Research and Public Health, 12, 9, 11724-11755. DOI: https://doi.org/10.3390/ijerph120911724.

Räisänen M.L., Kauppila P.M. \& Myöhänen T., 2010. Suitability of static tests for acid rock drainage assessment of mine waste rock. Bulletin of the Geological Society of Finland, 82, 2, 101-111. DOI: https://doi.org/10.17741/ bgsf/82.2.003.

Saitta E.K.H., Gittings M.J., Clausen C., Quinn J. \& Yestrebsky C.L. 2014. Laboratory evaluation of a prospective remediation method for PCB-contaminated paint. Journal of Environmental Health Science \& Engineering, 12 , 1, art. no. 57,5 p. DOI: http://www.ijehse.com/content/12/1/57.

Sinkkonen A., Kauppi S., Simpanen S., Rantalainen A.L., Strömmer R. \& Romantschuk M. 2012. Layer of organic pineforest soil on top of chlorophenol-contaminated mineral soil enhances contaminant degradation. Environmental Science and Pollution Research, 20, 3, 1737-1745. DOI: https://doi.org/10.1007/s11356-012-1047-1.

Smichowski P., Polla G. \& Gómez D., 2005. Metal fractionation of atmospheric aerosols via sequential chemical extraction: a review. Analytical and Bioanalytical Chemistry, 381, 2, 302-316. DOI: https://doi.org/10.1007/ s00216-004-2849-x.

Sormunen L.A. \& Rantsi R., 2015. To fractionate municipal solid waste incineration bottom ash: Key for utilisation? Waste Management Research, 33, 11, 995-1004. DOI: https://doi.org/10.1177/0734242X15600052.

Tokalioğlu Ş., Kartal Ş. \& Birol G., 2003. Application of a three-stage sequential extraction procedure for the determination of extractable metal contents in highway soils. Turkish Journal of Chemistry, 27, 3, 333-346. 